\title{
5. Journalists at risk: News media perspectives
}

\section{COMMINIHARY}

On May 22, 2009, Massey University's Wellington campus hosted many speakers addressing the conference on war reporting jointly organised by the International Committee of the Red Cross. Media speakers included Television New Zealand's Sunday programme reporter Cameron Bennett; Radio NZ political editor Brent Edwards; Fairfax NZ reporter Michael Field; Fairfax Media editorial development manager Clive Lind; Pacific Media Centre director and AUT University associate professor Dr David Robie; freelance foreign correspondent Jon Stephenson; and Radio NZ International news editor Walter Zweifel. Commentaries, in some cases transcribed from recordings of proceedings, have been abridged. This transcript was compiled by Massey journalism programme lecturer Alan Samson.

Keywords: conflict reporting, foreign correspondent, global reporting, humanitarian organisations, insurgencies, post-traumatic stress disorder, journalism training, war reporting, war correspondent

\section{Unions: Safety of journalists is our overriding concern}

\section{BRENT EDWARDS \\ Radio New Zealand}

I

T IS a sad fact of life that journalism in many parts of the world remains a dangerous craft. Too many journalists have died simply because they are journalists. Some are killed in conflicts, where they are simply in the wrong place at the wrong time. And that might be passed off as an occupational hazard of the job.

Those who cover war and conflict know the risks they run, but equally, too many journalists, not just in areas we would define as war conflict zones, are targeted specifically because of their reporting. In our region, the 
Philippines is a brilliant example, where more than 60 journalists have been murdered during president [Gloria Macapagal-] Arroyo's administration.

More journalists have died under the latest administration than under any previous presidency. So the question is also, how do we offer protection to those journalists working, for wont of a better word, in so-called danger zones, our colleagues in the region.

\section{Safety paramount}

Our [Engineering, Manufacturing and Printing] union, through its affiliation with the International Federation of Journalists, offers support and solidarity to journalists in many countries around the world, but particularly in this region. I've been to meetings, one in Hong Kong earlier this year, one in Kuala Lumpur in 2008, of the IFJ Pacific, where journalists' safety was the overriding issue for our colleagues.

It was interesting going from ...our hotel to the airport at the Kuala Lumpur meeting. When it finished, when I was travelling with the president of the Pakistan journalists' union and we were chatting in the taxi, he said to me, 'what are you doing about personal safety?' I reached around to put my seat belt on, and said, 'What do you mean?'

To me as a journalist working in New Zealand, I don't ever think about personal safety. But for him, it meant leaving home at different times every day to go to work, it meant changing his route to and from work every day. I mean there were a huge number of issues around safety for him, about how he got to his job, and the strain on the individual putting up with that day after day after day as a natural part of his work.

\section{Safety linked to a free press}

We are talking here about Kiwi journalists who might go away to conflict zones for a relatively short period of time and then fly back to the relative safety of New Zealand. You cannot separate the safety of journalists from the principle of a free press. For those societies that respect a free press, really, journalists' safety is not an issue.

We can't just talk about promoting systems and protections of journalists in the field - we need to promote in those areas of conflict, obviously the idea of resolving the conflict, but [also] the idea of promoting the principle of freedom of press in all of those countries. Because a number of 
journalists are saying, they're not working in conflict zones but they are working in countries where there is no respect for the media at all, and there is no respect for that ideal of a free press.

Therefore they are easily targeted and are often subject to visible intimidation and, in the worst cases, killings.

Brent Edwards, Radio New Zealand's political editor, has been a journalist since 1982, first working in Parliament's Press Gallery in 1989. He chairs the Engineering, Printing and Manufacturing Union's media council and is a former member of the NZ Press Council. He brought a perspective from the AsiaPacific on the issue of warreporting after recently having attended the International Federation of Journalists conference in Hong Kong where safety was the key issue.

Brent.Edwards@radionz.co.nz

\section{The seduction of war - and when to take one step back}

\section{MICHAEL FIELD}

Fairfax Media

\section{Worth getting killed for?}

COVERING conflict has a kind of seduction to it - and many a good reporter and photographer has fallen for its spell. Photographer Robert Capa's dictum about good photos ('If your picture isn't good enough, you're not close enough') is the obvious caution here.

For myself, I've obviously yet to find the story that is good enough to get killed for... and I feel sadness for those of our colleagues who pay that price anyway. That said, there is the adrenalin buzz of the whole thing.

\section{Finding the line of control}

I have simply taken on board the advice of a chap I knew years back during some earlier conflicts who used a Kashmiri term to be his guiding principle. 'Find the line of control,' he would say, 'and stand one step back from it.'

On the one real occasion I remember applying it, I cannot say whether I would have necessarily been killed had I been one stop across the other 
side - but I would have been in trouble.

Even the best of journalists can get seduced by some of the trappings of conflict. I myself have a particular passion for military aircraft and ships, and love riding on them. Happily in New Zealand, they seldom go into harm's way. Oddly, the most stressful part of all that for me was some years ago when my son, a navy officer, was assigned to the early stages of the Timor peace keeping operation. The pure relief of seeing his ship come around North Head and dock at Devonport after all the weeks of sitting home worrying about him remains vivid for me.

Conflict has another benefit for reporters: it's a form of escape. I remember once going for days in a tense situation - and then realizing how I was enjoying it only when I suddenly remembered I had not paid my electricity bill before leaving home.

But there is a greater cause, and it is here that I want to draw on an odd experience I had in the Solomon Islands in the late 1990s during the ethnic conflict - at a time when none of the big guns of the region were interested and the Solomon's was left to its own anarchy.

The man I was speaking to had killed an old man the day before-and he had also killed the baby, the man's grandchild, as he held the child. I remember the oddity of actually interviewing such a person-he was not, so far as I could tell, especially evil.

In this village this chap - who wore bamboo curtain rings in his hair and imitation camouflage clothing - told me they were fighting a holy war. He said: 'The trees are fighting, the stones are fighting, and the women and the children are fighting.'

Trying to understand this hatred between people who had lived side-byside for a thousand years or more was difficult and I asked the man what it was that he did not like about Malaitans. 'Do you know what we call them,' he said, 'dog sperm.'

Plainly there is a question to be answered over whether to report such a thing. One would have to consider your audience in the first place.

At the time I was with Agence France-Presse and my primary concern was an international audience, rather than a local one. So I reported it.

Now the Solomons only had a glimmer of internet then but, thanks to Radio Australia, the quotation came bouncing back into the Solomons. Needless to say it caused outrage and Johnson Honimae of the government radio 
service — and more recently with the Pacific Forum Secretariat — assailed me for months later.

'Overseas journalists don't care what happens as a result of their stories,' he said. 'If that reporter was in Honiara, he would have been killed.' Actually when he said that I was in Honiara - and wasn't killed. Several of us were taken hostage and rescued by former Fiji Prime Minister Sitivini Sitiveni Rabuka, working as a Commonwealth negotiator but, for the most part, I was okay.

The man who uttered the infamous remark that I quoted went on to get a degree at the University of the South Pacific in Suva and returned home, apparently to go quite mad. The old Latin Catholic in me suggests he was paying the wages of $\sin$.

\section{To report or not to report}

But the question of what to report and what not to report-particularly when you are up close and personal-remains in my mind.

I actually don't know if there is a right answer or a wrong answer. What I do know is that, in asking the question and retelling the answer, I was clearly thinking about the people who had been killed the day before.

I say that as a roundabout way of saying that I was not especially trying for a graphic quote, but seeking to put some light into darkness. Hate and evil is real-you can taste and smell it in the midst of tension and drama.

It is perhaps unreasonable to expect us reporters to reconstruct the world and end all hatred and evil. But by shaping the beast and throwing some light on it, perhaps it is possible that we can draw humanity into resolving conflicts and repairing souls.

Perhaps I am being somewhat naïve, but I think our job in covering war, and in covering conflict, is just as much about covering it one victim at a time, one killer at a time, as it is to write about the grand politics and strategy behind it all.

I am not at all romantic enough to believe that wars will come to an end and I would - perhaps at a different forum - tell you where the next nasty ones are going to occur.

But it's our jobs as reporters to make sure that nobody can ever say, 'but we never knew it was happening'. 
Michael Field, a reporter working out of Fairfax NZ's Auckland bureau, has had a long career covering the Pacific, including for Agence FrancePresse and The Dominion. His more than 30 years of journalism has included coverage of Fiji's 2000 and 2006 coups. He was banned from Fiji by the military regime in 2007. He is the author of books on Samoa's independence struggle and Fiji's coup with his latest book, Swimming With Sharks (Penguin), due out in August.

mjfield@clear.net.nz

\title{
Television: The importance of a reporter's face viewers can relate to
}

\author{
CAMERON BENNETT \\ Television New Zealand
}

\section{Someone to empathise with}

THE SORT of stories that my programme Sunday, would commit to in the past-be they Iraq, Afghanistan, Palestine, Zimbabwe, Ivory Coast, Burma - are now pretty much off the radar. Instead we're buying in our coverage because it's cheaper.

Make no mistake, some of it is excellent, and the result of a much greater commitment than we would ever be able to give. So why is this a problem? Well in my experience, we've discovered viewers relate much more strongly to an issue, or human suffering, if it's interpreted by someone that they know and trust, a reporter, a face, a brand, for want of a better expression.

Turning to a local subject that our programme has kicked off in the last week, which is about the intensive farming of pigs, legalised cruelty, question mark-you should have seen the response, well, you have seen. It's driven the news agenda this week [May 2009]. It's not the first time the issue of apparent cruelty to pigs has been brought into the public arena but never can I recall it having such impact as this.

Why? Well, a critical reason for this story resonating the way it did was that it used [comedian] Mike King who had been the face of the Pork Board as the whistle blower. So it had the potency of who was the whistle blower 
but, more importantly than that, he empathised with the animals. He brought you in to where they were suffering and you kind of felt it through his eyes.

Wouldn't it be great if human issues resulted in the same passion and interest? What I'm saying is, so often television coverage of human suffering abroad, resonates at home when it's brought home by someone folks know, who can bring the very sense of empathy that's being discussed today, through an experience, and translate it and interpret it to people back home.

\section{Enter the gatekeepers}

I went up to cover, post- [Indian Ocean] tsunami, the damage in [Sri Lanka's] northeast. It was terrifically miserable, countless deaths had happened up there, but now of course, post the rounding-up and the ending of the 26-year civil war, there's a [further] issue of some 300,000 people that may well be housed in concentration camps, certainly are behind wire.

Already there have been reports from Channel 4 [Australia] and the like of abuses occurring, rape and so forth. These are the early days. Guess what, we're not going. We went for the tsunami, but we won't be going for that. Why?

Well, bottom line, no money. But, more recently, when I was encouraging that we cover this story, it was met with the news editor response: "hang on, there are lots of stories around the globe, why should we single that one out?"

We run up against this sort of stuff. Parochial New Zealand gatekeepers constantly argue that foreign stories don't rate and therefore are not worth covering. That's an ongoing internal struggle for us. So how do we cover an event like that? We get buy-ins, of course.

\section{Working with NGOs}

But couldn't it be more interesting? The Red Cross is about to send a nurse to work in the camps up there. We made a direct response to them about what would be the chances of taking a camera with her, and maybe looking at a video diary or something similar, to localise it a bit better for us, to bring a local understanding and sensibility and understanding of that story.

Now, my understanding was that that was turned down, largely because it was seen to be too compromising of the work of the ICRC. It's an interesting and vexing position this one. Where does it leave the likes of TVNZ's viewers? Her work deserves all the profile it can get, but how will she get that if no-one goes there to cover it? 
We talk of the 'CNN factor', where foreign policy itself is sometimes affected by media coverage, but there's a flip side to that. What about when there is no CNN factor, because we don't make it to the zones in the first place. If the CNN factor is a real dynamic, then it follows that the opposite will occur because there is no coverage in the first place.

I would suggest, as part of the debate here, with an NGO like the ICRC, that we rethink positions a little bit, that we give some serious consideration to cost-splitting jobs, if you like, or finding a way in which a local media channel like ours, or another, can get to a zone in the first place, when there's no money around.

Compromising, it doesn't have to be, for either party. Yes, it can be acknowledged that the collaboration's occurred in the first place. Yes, television in particular, frustrates the hell out of agencies such as the ICRC, for all the obvious reasons that have been mentioned today: oversimplification of complex crisis situations, but this is the reality, it is what it is.

Television's largely there to present the human face of a tragedy. An analysis and deeper understanding can be presented through other media. In a media like mine, that's what it deals with. It deals with well, when a crisis breaks out. So that's what I'd like to leave us with today, the idea of a crosspollination, when it comes to costs.

Cameron Bennett is host and senior reporter of TVNZ's Sunday programme. Formerly TVNZ's Europe correspondent, his assignments have included reporting the Bosnian civil war and the post-genocide exodus from Rwanda. Reporting assignments have taken him from Somalia to Palestine, Iraq to Afghanistan, as well as Zimbabwe, Ivory Coast and Sri Lanka.

Cameron.Bennett@tvnz.co.nz 


\section{The challenges, risks and rewards of reporting conflict}

\section{JON STEPHENSON \\ Independent Journalist}

REPORTING on conflict is incredibly interesting and deeply rewarding, on both a personal and professional level. It is also difficult and often dangerous work - arguably the most demanding area of journalism. Just getting access to the story can be a major challenge, as reporters who struggled to enter Iraq to report on the US invasion in 2003 can attest.

For journalists reporting from foreign lands, there is a host of language and cultural issues to deal with, and newsgathering in an unfamiliar and hostile environment can really test one's resilience. While developments in technology such as portable satellite phones and email have made reporting from the field much easier, journalists covering conflict or disaster in places like Somalia, Afghanistan or Haiti can still find themselves having to operate with limited resources.

Just securing accommodation and transport — and even a reliable supply of food or water — can be problematic; communication may be limited and information difficult to obtain or verify. People can be hard to find, and, even when contact is made or a person's location established, getting to-and-from an interview safely may be impossible.

Indeed, reporting war has, in recent years, become increasingly dangerous. According to the Paris-based organisation Reporters Sans Frontières, 66 media workers were killed in Iraq between March 2003 and August 2005 alone - more than were killed in the Vietnam War; which lasted two decades (from 1955 to 1975).

Media in hostile environments like Russia, Columbia, and the Philippines have also been badly affected by this trend. Disturbingly, most have been targeted-killed to stop them doing their work. And while the great majority of journalists killed in the past decade have been local reporters, foreign reporters are well-represented in the numbers.

An additional challenge for journalists reporting conflict is learning to deal with the impact of trauma or post-traumatic stress - not only in terms of self-care but the duty of care we have to those profoundly damaged individuals we encounter in our work. 
Learning how to deal with psychological challenges is an issue that for years was given scant attention by our profession but one that is assuming greater importance. One study, by psychiatrist Anthony Feinstein, suggests 28 percent of war reporters will at some point in their career develop posttraumatic stress disorder (PTSD).

None of these challenges - the physical and psychological risks facing war reporters, in particular - should be under-estimated. Yet some of the most frustrating challenges facing journalists who cover conflict are not those on the battlefield but in our newsrooms. I am referring to the cost-cutting within the media industry, both here and overseas, which has had an impact on reporting in general and on foreign affairs reporting in particular.

This is hardly surprising, as good foreign affairs reporting, like investigative journalism, another badly affected area of the profession, requires experienced, well-trained, and well-resourced staff-none of which comes cheap.

More recent media cutbacks in the United States have exacerbated a downturn in foreign affairs reporting that began in the late 1980's-early 1990s when US television networks began closing some of their key overseas bureaus, opting to 'parachute' correspondents in from time-to-time to cover stories.

In the October/November 2003 issue of American Journalism Review, John Schidlovsky, director of the Pew International Journalism Program, described this decline in the quality and quantity of international coverage as 'perhaps the single most negative development in journalism in my lifetime'.

'The reasons the networks give for closing bureaus are well-known and justifiable in that maintaining foreign bureaus is extremely expensive. But the cost has been that the American public knows so much less about what's going on in the world than 30 or 40 years ago....'

Says Schidlovsky: 'It becomes a vicious circle: When the public knows less about places in Africa or Asia or Central America, then it is going to demand less, and then the networks say the people aren't interested, and that becomes the pretext for dropping off.'

Anyone familiar with journalism in New Zealand will know that the situation here in terms of financial support for quality foreign affairs reporting is also bleak.

Whether this really matters - whether it is important for a small country like ours to train and sustain foreign correspondents, and, if so, which stories they should be sent to cover-has been the subject of some debate. Clearly, not all foreign news stories justify the cost or risk of dispatching a reporter. 
It seems strange, however, that media companies in a supposedly firstworld nation spend large sums sending journalists around the country to report what some might see as trivial issues (or to cover sport overseas), yet baulk at reporting an issue like the conflict in Afghanistan-now the longest war New Zealand has been involved in.

Either way, those students here that are interested in becoming a war correspondent or a foreign correspondent should be under no illusion about the commitment this entails and the lack of financial and institutional support they can expect - especially if they choose to work as a freelance.

A lack of resources or financial support can make what is a difficult job even more demanding and occasionally more dangerous. There are journalists who would doubtless be alive today had their news organisations invested in hostile environment training or ensured staff had the necessary knowledge and equipment to provide emergency first aid.

Similarly, many reporters would be more effective when they returned from the field or returned to the field if they had access to counselling or the opportunity to debrief after an exhausting assignment.

Much has been done in recent years by companies like Reuters to prepare and support staff members who operate in conflict zones-and some of that support, such as training, safety equipment, and insurance, is being offered to freelancers or local staff that work in countries like Afghanistan. Much remains to be done, not least in countries like ours.

Ideally, we could start in journalism schools, with classes in foreign affairs reporting as part of the syllabus. It has always amazed me that in New Zealand we teach almost every aspect of journalism except this - despite the fact that we live in such an interconnected world. If we took foreign affairs reporting seriously we would encourage journalism students to develop their knowledge of world events, to study a language, or learn the basics of international law.

Sadly, there are few signs this will happen, and the fact that many news organisations are under fire financially will continue to make things more challenging for media personnel who come under fire in the field. Trends suggest that journalists, like many others, will have to get used to doing more with less, for the foreseeable future at least.

Notwithstanding the challenges, we should not lose sight of the importance of reporting conflict and the possibilities it offers to effect change. James 
Nachtwey, perhaps the leading war photographer of his generation, put it well when he said: 'Photos and news reports are a kind of intervention. They keep things from happening in the dark. They give people a voice. They create consciousness, and from consciousness, conscience grows.'

He added: 'I think we do have to put ourselves on the line and keep going out there, because it does make a difference. Each one of us is only a grain of sand on the beach, but all together we make an impact.'

Those among you who one day have the privilege of reporting conflict will get the chance not only to bear witness to history and put your skills to the test but to make the sort of difference Nachtwey talks about. I encourage you to make the most of that opportunity.

Jon Stephenson is a freelance foreign correspondent based in New Zealand. He has reported on conflict in Afghanistan, Iraq, the Palestinian Territories, Lebanon, and Zimbabwe. jonrstephenson@gmail.com

\title{
Media under fire: Pacific 'self-determination' insurgencies and the student press
}

\author{
DAVID ROBIE \\ Pacific Media Centre
}

\section{'Bloodless' coups}

A FOCUS on war and embedded coverage on the global stage has meant that many smaller conflicts closer to home have been ignored or seriously under reported, such as "self-determination" insurgencies. The lack of mainstream media resources has often meant a reliance on freelancers taking risks, usually with limited news organisation logistical or safety support.

Astonishingly, the Paradise stereotype still lingers in Pacific-region reporting, but the reality is often conflict-driven, such as in Fiji, Timor-Leste and West Papua. While much is often made of the four so-called bloodless coups in Fiji, in fact more than a score died after the George Speight coup in 2000 and almost a third of East Timor's population - or a guesstimate of 250,000 


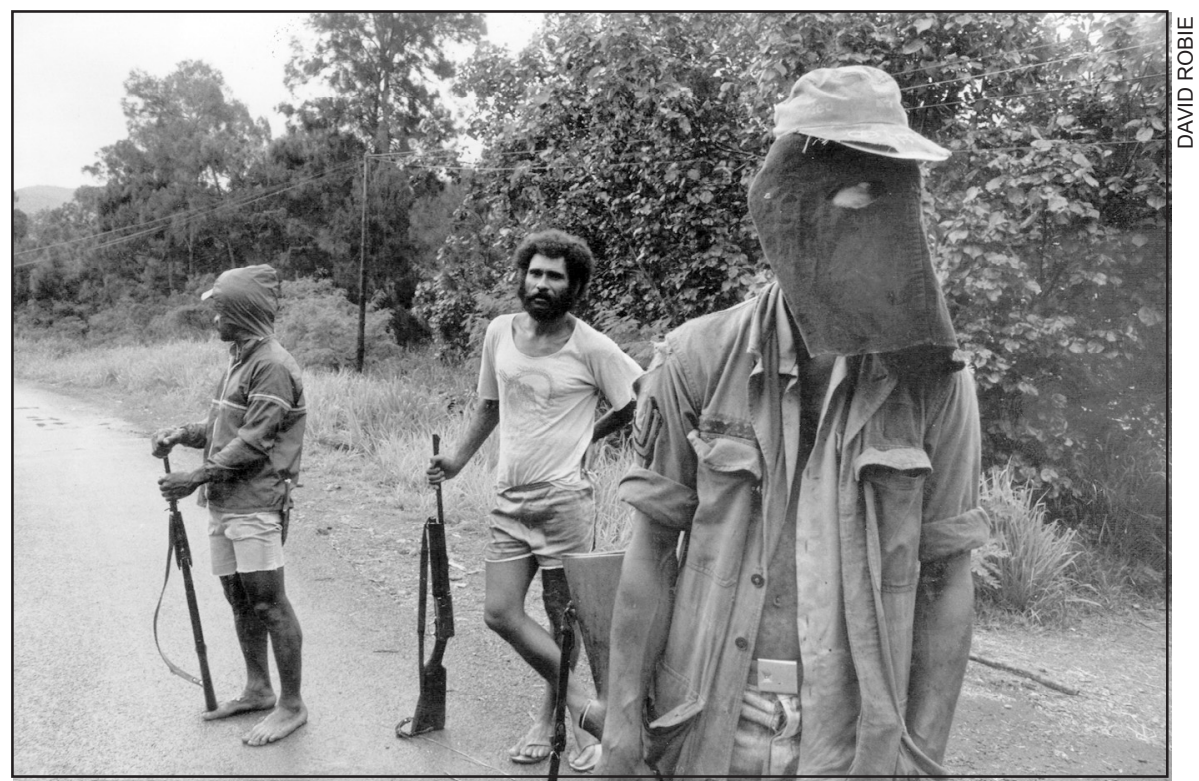

Kanak militants on the road to Thio, New Caledonia, in the insurrection of 1984.

people - perished in the quarter century of Indonesian occupation from 1975.

An additional protocol (Article 1, Protocol 1) to the Geneva Conventions emphasises the conventions include cover of conflicts "in which people are fighting against colonial domination and alien occupation and against racist regimes in the exercise of their right to self-determination".

As a freelance journalist travelling widely in Kanaky/New Caledonia in the mid to late 1980s, I reported extensively on the Kanak struggle for selfdetermination against French colonialism. This was a period of considerable unrest, protest, armed conflict, massacres and assassinations.

People I reported on included Eloi Machoro, a Kanak schoolteacher who was thrust into the leadership of the militant wing of the Kanak National Liberation Front (FLNKS). Depending on which side of the political spectrum they were, observers branded him as the 'Robespierre' or the 'Che Guevara' of the Pacific. Neither epithet was accurate. But he became public enemy number one of the French colonists.

One of the most symbolic events of this period of conflict was when Machoro and his followers seized a ballot box in Canala during a referendum on French rule. He chopped open the box and set fire to the ballot papers. 
My photographs of this incident were widely syndicated. Machoro and one of his lieutenants were later assassinated on 12 January 1985.

During this period, large groups of armed and often masked Kanak militants were in action through the East Coast of La Grande Terre island-more than two decades before the Speight militants of Fiji. One month before the assassination of Machoro was the massacre of Hienghène, an east coast township in New Caledonia (Robie, 1989, p. 105). Ten unarmed Kanak villagers from nearby Tiendanite, including two brothers of the peaceful Kanak leader Jean-Marie Tjibaou were gunned down in an ambush. A harrowing eventmore than half of the men in the village perished in one night of horror and the consequences for the rest of the village were devastating at the mass funeral.

The charismatic leader Tjibaou-along with his deputy Yeiwene Yeiwene - was himself assassinated in Wadrilla, Ouvéa, for a perceived betrayal of the Kanak people because of the compromised Matignon Accord agreement. This happened on 4 May 1989, on the eve of the anniversary of the Ovéa cave massacre, when French troops killed 19 Kanak militants and tortured others.

The disillusioned militant who killed Tjibaou, Pastor Djoubelly Wea, was immediately gunned down by bodyguards. Just a few months earlier I had shared a hotel room with this assassin for two days in Manila, Philippines, and found him to be a charming, friendly character.

\section{Hoping for the best}

During this period I was constantly threatened by militant supporters of French rule as I was perceived to be sympathetic to Kanak self-determination - which I was - but I was passionate about telling the untold stories and balancing the news agency bias. I was twice arrested by French troops in New Caledonia. As an independent journalist, my stories and pictures were widely syndicated to global media, generating far wider international responses than in New Zealand media, which was largely disinterested in the Francophone Pacific (although I had many articles published in The Dominion, New Zealand Times and The Listener).

During the first year of the Bougainville conflict in 1988, I reported widely for Pacific media, including a cover story that I wrote for Pacific Islands Magazine about the war zone on the ground. As a freelancer working in the Pacific during this period, there was little debate about 'duty of care' or safety of journalists as happens now. It was simply a matter of taking calculated risks and precautions - and hoping for the best.

62 PACIFIC JOURNALISM REVIEW 16 (1) 2010 


\section{Journalism students in conflict zones}

The challenges facing student journalists covering conflicts are similar to freelancers, particularly in developing countries - no security, no institutional support and no logistics. A very real danger with often limited training.

During the George Speight coup in May 2000, I had a different role. Rather than reporting the conflict myself, I was supervising a team of pan-Pacific student reporters based at the University of the South Pacific covering the political crisis and editing their stories.

They published their daily news website, Pacific Journalism Online, and their newspaper, Wansolwara. They started reporting the conflict from day one on 19 May 2000, and felt obliged to continue as the putsch stretched into days, weeks - and then months (Cass, 2002; Robie, 2001, 2003).

Martial law was declared and a curfew. The university, which was officially closed, shut down our website with no consultation on the day martial law was declared. I thought at first that military authorities had gagged us as part of the clamp down. I faced a major dilemma: Shut down the journalism programme along with the rest of the university, or carry on and defy the curfew and risk a major fallout with academic authorities if anything happened to any of our students. I had sleepless nights wondering about worst case scenarios.

But the volunteer students wanted to carry on and I wasn't going to deny them this opportunity of the story of a lifetime. The University of Technology, Sydney, through its Australian Centre for Independent Journalism, set up a special website for their gagged stories and they carried on reporting. They won a string of awards for their frontline journalism and the faculty later passed a unanimous resolution endorsing the journalism students' actions, saying that their news coverage had actually contributed to the safety of university staff and community.

Actually, many of the journalists working on news media organisations were younger and less experienced than some of our students - but they did have the advantage of being fully supported by their media organisations.

\section{References}

Cass, P. (2002). Baptism of fire: How USP journalism students covered the 2000 coup. The Round Table: The Commonwealth Journal of International Relations. 366, 559-574.

Robie, D. (2003). Cyberspace democracy: Freedom of speech issues in Pacific journalism education. UTS Law Review. 5: 131-149. Retrieved on 13 January 2010, 
from http://heinonline.org/HOL/Page?handle=hein.journals/utslr5\&div=13\&g_ sent $=1 \&$ collection $=$ journals

Robie, D. (2001). Frontline reporters: A students' internet coup. Pacific Journalism Review, 7: 47-56. Retrieved on 13 January 2010, from http://kauri.aut.ac.nz:8080/ dspace/bitstream/123456789/44/1/Pacific\%20Journalism\%20Review\%20 \&_1_47-56_Frontline\%20Reporter.pdf

Robie, D. (1989). The massacre of Hienghène. In Blood on their banner: Nationalist struggles in the South Pacific (pp. 105-115). London: Zed Books.

Dr David Robie is director of the Pacific Media Centre at AUT University and convenes Pacific Media Watch. He reported self-determination conflict struggles in Africa and the Pacific, mainly as a freelance journalist reporting for international media, and is the author of books including Eyes of Fire, about the Rainbow Warrior bombing, Blood On Their Banner: Nationalist Struggles in the South Pacific and Mekim Nius.

david.robie@aut.ac.nz

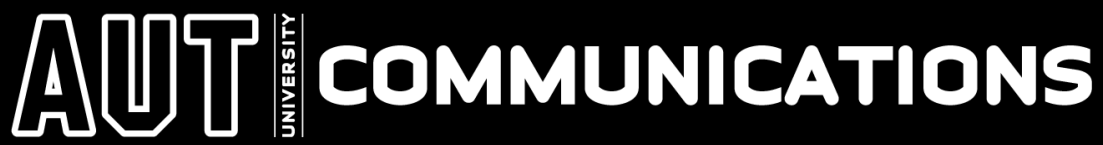

\section{POSTGRADUATEJOURNALISM}

Bachelor of Communication Studies(Hons) offers students either an applied or an academic pathway incommunication studies. Papers and strands include Asia-Pacificjournalism, digital media, investigative journalism, public relations and screen writing.

Master of Communications Studies(MCS) is a postgraduateresearch degree offering practical options.

Doctorate in Communication Studies $(\mathrm{PhD})$ is a thesis-based research degree granted on the basis of $x$ original and substantive contribution to knowledge. The Faculty of:Designand Ereative industries encourages and supports innovative interdisciplinary research. The School of Communication Studies has supervisingstaff whose research interests cover a range of areas encompassing media, politics and ownership, journalism, human communication, new media and development, discourse analysis and popular culture.

Email: commstudies国aut.ac.nz

Web: www.commstudies.aut.ac.nz

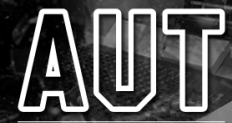




\title{
An audit of what news' bosses should provide
}

\author{
CLIVE LIND
}

Fairfax Media

GIVEN my lack of direct experience in reporting war zones, I thought I would flip the exercise on its head. I thought I would pretend I was an auditor told to investigate what I would be looking for if a newspaper or news media organisation had sent a correspondent into a war zone, or known dangerous areas, and that a correspondent had been injured.

\section{Audit findings}

1. The journalist should have been trained in reporting dangerous situations. The journalist would have been on a course similar to the ones [risk mitigation company] AKE runs in Australia. Thus, the correspondent would be well aware of what [he or she] is likely to find in the particular hostile zone. As AKE says, you're likely to find chaos, no absolutes and, therefore, your first line of defence is your own awareness.

2. The correspondent would have had been given sufficient time to learn, or was already aware of what he or she would be likely to find: the political situation, the parties involved, as much history about the hot spot as they could muster.

3. The reporter would have had all the necessary inoculations and that [he or she] knew of likely health hazards. The reporter would also have a basic medical kit and the skills necessary to look after [him or herself] in the event of minor injuries. That would include being able to give self painkilling injections.

4. The journalist would have had a comprehensive medical insurance programme that people in any hospital or medical clinic could recognise and act upon. That insurance policy would include flying out our injured correspondent.

5. The individuals involved would have been tested for self-sufficiency, that they knew how to look after themselves, how to plan and think ahead, and were able to define objectives and the risks associated with them. 
That sort of testing would be at a basic level-that somebody who can't stand tropical climates isn't sent to one to cover a war.

6. The journalist would have plenty of money-probably in US dollars, given that's an internationally accepted currency. The right amount of money can mean the difference between life and death, so it has to be thousands of dollars, not hundreds. I would expect to find that likely currency requirements were known before the correspondent left. And l'd expect to find that Visa cards etc were well topped up. I would make sure my audit did not include details of whether they were meant to bring back receipts.

7. The reporter would have had sufficient money to pay for translators and the like, that all sources of support and aid were known beforehand and that these possible sources were well known back home as well.

8. My audit tick boxes would see that the correspondent had all the necessary IT equipment such as satellite phones, cell phones, laptops, BlackBerries and so on-in other words, that IT staff had checked out local internet providers and telcos and the like and that they knew the equipment would work in a particular region. l'd also expect to find that the correspondent was skilled at using such equipment.

9. Some recognition that taking the pictures (or getting the story) in such places is often the easy part. Getting them back home is often the hard part, and sheer cunning and wiliness is often required to achieve that goal-in other words, knowing how to flick a few bucks around to achieve ends.

10. Then there's the other equipment they should have-bullet-proof vests, helmets, good boots, etc. It would depend on where they were going, but that sort of gear is available and correspondents should have it.

11. The journalist would have made some effort to recognise that you can't drink the local water and that they had taken, or knew where to find, reliable water bottles. As well, l'd like to find they had a good knowledge of local food and, as a precaution, a supply of high energy food bars to keep them going, all the time recognising, of course, that they would work best when travelling light.

12. Finally, the reporter would have a buddy system back home, somebody whose job it was to stay in touch with the correspondent, know of their 
issues or any problems, who could fix them. That person should have been in daily touch with the family of the correspondent-in my experience, we have some way to go on the latter-making sure they know how she or he is, and facilitating direct contact

\section{Conclusion}

If we've accomplished all this, in spite of our injured correspondent, now recovering at company expense back home, I as auditor would give our employer a pass. Injuries and worse have to be expected in war zones and dangerous places and, sadly, all too often that is what comes to pass.

Fairfax Media NZ audit manager Alistair Storm; AKE Group, Colin MacKinnon, Glen Lynden, Fairfax Media Australia; International News Safety Institute; Reporters Without borders.

Clive Lind is editorial development manager at Fairfax Media where, since 2004, he has been responsible for overseeing the editorial development of the Fairfax group. During a long career as a journalist, he was the editor of three New Zealand daily newspapers, the Manawatu Standard, Wellington's Evening Post and Invercargill's Southland Times.

Acknowledgements to Fairfax Media NZ audit manager Alistair Storm; AKE Group, Colin MacKinnon, Glen Lynden, Fairfax Media Australia; International News Safety Institute; Reporters Without Borders. 